\title{
Practice and the Influencing Factors of Nurses Working in the Intensive Care Unit regarding Physical Restraint use: Multi-centered cross- sectional study
}

Tilahun Kassew Gebeyehu ( $\nabla$ tilahunkassew123@gmail.com ) University of Gondar College of Medicine and Health Sciences https://orcid.org/0000-0002-8726-4169 Ambaye Dejen Tilahun University of Gondar College of Medicine and Health Sciences

Bikis Liyew Wudu

University of Gondar College of Medicine and Health Sciences

Research article

Keywords: Intensive care unit, Nurses', Practice, Physical restraint

Posted Date: March 9th, 2020

DOI: https://doi.org/10.21203/rs.3.rs-16391/v1

License: (c) (1) This work is licensed under a Creative Commons Attribution 4.0 International License. Read Full License 


\section{Abstract}

Background: Nurses working in the intensive care unit commonly use physical restraint on critically ill patients. The main reason for the restraining of patients is to prevent the dislodgement of invasive procedures/ medical equipment, reduce agitation. Patients are exposed to different complications from physical restraint like worsening of agitation and delirium, fall injury, limb edema, restricted circulation, and skin laceration at restraint site, and death as a result of nurses' improper practice regarding restraining. Despite this impact, there was no documented study in Ethiopia in this regard.

Objective: To assess practice and its influencing factors of nurses working in the Intensive Care Unit regarding physical restraint Methods: An institution-based cross-sectional study was conducted from July to August 2019 at Amhara regional state referral hospitals, Northwest Ethiopia. All (260) nurses working in the intensive care unit were invited to participate through a convenience sampling technique. Structured questionnaires which consist of socio-demographic, professional characteristics and Level of Knowledge, Attitudes and Practices of Staff Regarding Physical Restraints Questionnaire were used. Simple and multiple linear regression and beta $(\beta)$ coefficient at $95 \%$ confidence interval was employed with $p$-value $<0.05$ as statistical significance.

Result: The mean score of nurses' practice regarding physical restraint use among critically ill patients was $30.94 \pm 5.44$. Nurses with short ( $\leq 2$ years) experience of the intensive care unit, received educational training during graduate class regarding restraining, knowledge and attitude scores were the factors significantly associated with nurses' practice score regarding physical restraining use.

Conclusion: The practice regarding physical restraint use among critically ill patients among participant nurses' was a satisfactory. The administrators' should develop and provide educational and in-service training programs for nurses working in intensive care unit settings regarding physical restraint use and its alternatives, which is crucial for the nurses' to improve their behavior of restraining. Keywords: Intensive care unit, Nurses', Practice, Physical restraint

\section{Background}

Physical restraint (PR) refers to any physical devices or methods attached to or near the patient's body which restricting a person's freedom of movement, physical activity or normal access that could not be controlled by the patient $(1,2)$. Physical restraint is used in hospitals when patients' are confused when the alternative methods are inadequate and physically harmful to themselves and others $(1-3)$. About $80 \%$ of critically ill patients who are admitted to the intensive care unit have agitation, confusion, sleeplessness, and disruptive behavior (4). Intensive care unit (ICU) health professionals try to reduce those behaviors by using different measures like lowering bed height, raising bed rails, using the sedating medication before physical restraint $(5,6)$. So health professionals in the intensive care unit use physical restraint to reduce the risk of a patient's falling, prevent removal of life support equipment and procedures, and reduce the risk of patients harming himself or others (1). Several works of literature 
reported that physical restraint use range from 3.4-79\% worldwide (7-10). As a result of its purpose, physical restraint (PR) is commonly used in ICU. Studies indicated that nurses do not believe that using physical restraints in hospitals can result in restlessness, aggression, and injury (11).

Good quality of service at ICU is predicted by a nurse's practice (behavior) regarding PR use on critically ill patients (12). Improper nurses' practice regarding PR use is common in ICU settings with the prevalence rate of its items range 1.7\%-75\% (13-16). This causes a high rate of complications associated with PR due to insufficient use $(17,18)$. According to different published studies report, the mean score of practice range 17.08-45.44 $(8,15,19)$ Researches showed, restrained patients in the ICU encounter prolonged hospital stays and adverse psychological and physical consequences like agitation, aggression, limb edema, and skin laceration at restraint site, and fall which resulted in a poor quality of health care system $(7,20,21)$. Different studies (22-25), have shown, more than half of critically ill patients have restrained and they faced complications from PR due to improper practice of nurses on it. Yet, despite these potential complications, there are insufficient guidelines and regulations on the use of physical restraints present itself as a serious problem (26).

The influencing factors of nurses' better practice on PR use were male in gender, longer year of experience, and longer working years at ICU, day shift work, and higher academic qualification, lower number of patients care per day, getting In-service and educational training regarding $\operatorname{PR}(10,13,15,17)$. Nurses' knowledge and attitudes regarding PR is an important factor for providing good care for critically ill patients. Favorable knowledge and a better attitude towards PR of nurses can improve their practice on alternative strategies and physical restraint, and minimizes physical, psychological and ethical dilemma problems associated with PR $(4,17,27)$.

Even though ICU nurses' practices have an impact on the use of physical restraint, there is no study that shows the practice of nurses working in ICU regarding PR use in Ethiopia. So identifying nurses' practices regarding physical restraint use is crucial for improving nurses' behavior on the application of PR use among critically ill patients. Again this contributes to using alternative strategies to minimize physical, psychological and ethical dilemma problems associated with PR to improve the quality of care among critically ill patients. Hence the aim of this study was to assess the practice and its influencing factors of nurses working in the ICU regarding PR use at Amhara regional state referral hospitals, Northwest Ethiopia.

\section{Methods}

Multi-centered institution based cross-sectional study was conducted among nurses working in ICU at Amhara Regional State Referral Hospitals (ARSRHs), Northwest Ethiopia from July to August 2019. There are five referral hospitals (Felege-Hiwot, Dessie, Debre-Markos, Debre-Birhan, and University of Gondar referral hospitals) in which intensive care is provided for critically ill patients. Nurses who were working at neonatal and pediatric ICU, on annual leave during data collection, head nurses were excluded from the 
study. All nurses ( $n=260)$ in those hospitals invited to participate; however, 237 nurses have participated with their willingness through convenience sampling technique.

\section{Data collection procedure and tool}

Structured self-administered questionnaires including socio-demographic, professional characteristics and Level of Knowledge, Attitudes and Practices of Staff Regarding Physical Restraints Questionnaire were used. Data was collected by five nurses who were the heads of each ICU ward who distributed the questionnaires to the respondents by getting their willingness and collected the filled data. The questionnaire was prepared by the researchers in the English language which is used for the collection of the information. Each questionnaire was accompanied by an information sheet that described the objective of the study and explained participation was voluntary with written consent. The questionnaire format was filled in their clinical area by the respondent nurses in the presence of the data collectors.

The nurses' practice regarding PR use was measured by using the practice part of the Level of Knowledge, Attitudes, and Practices of Staff Regarding Physical Restraints Questionnaire. On the other hand knowledge and attitude, parts were used for assessing nurses' knowledge and attitude respectively. The tool was initially developed by Janelli, Scherer, and Kuhn (1994) (28) and then improved by Suen LKP (1999) (29) again which adapted by Kaya et al. in 2008 (30).

The first part of the scale consists of 11 items that have 10 correct questions and 1 false question which measures the knowledge of nursing staff regarding the use of physical restraints. The participants' responded to the questions were agree or disagree. The correct answer is scored as 1 , and the wrong answer is scored as 0 . The total score range of knowledge is $0-11$; nurses with the total score closer to 0 indicate the very least level of knowledge and those with the total score closer to 11 indicate the highest level of knowledge. The second part is a 4 point likert scale that has 12 items and measures attitudes of nursing staff regarding the use of physical restraints; and responses are "strongly agree" $=4$ point, "agree" $=3$ points, "don't agree" $=2$ points and "strongly disagree" $=1$. The total score range of this part is 12-48; nurses with the total score closer to 12 reveals very poor attitude and those with the total score closer to 48 reveals the best possible attitude regarding PR use. The third part consists of 14 items to measure practices of the nursing staff regarding the use of physical restraints. The 10 th item is a negatively worded item and is scored reversely. The participants responded in a 3 point likert scale "never" $=1$, "sometimes" $=2$ and "always" $=3$. Total scores range 14-42; nurses' with a total score closer to 14 reveals most undesirable/ improper practices and scores closer to 42 indicates excellent/ proper practices regarding PR (28-30). Cronbach's alpha coefficient of the practice part of this study was 0.82 .

\section{Data processing and analysis}

Coded variables were entered into Epi-Data version 3.1; then exported to IBM SPSS version-20 for analysis. Frequency, percent, mean, standard deviation and range were used to summarize and evaluate the distribution of variables. After performing assumption tests, simple linear regression was performed to determine the correlation of each independent variable with the practice score. Variables with $p$-value 
$\leq 0.2$ during simple linear regression were selected for multiple linear regressions for further analysis and model fitness test (adjusted $\mathrm{R}^{2}$ ) were also checked. Factors associated with the nurses' practice regarding PR use were expressed as adjusted unstandardized $\beta$ coefficient by employing a $95 \%$ confidence level. A $p$-value of $<0.05$ was considered statistically significant.

\section{Results}

A total of 237 participants took part in the study, with a response rate of $91.2 \%$. The mean age of the participants was 30.50 (SD, 9.93) ranging from 25 to 40 years. The majority of the participants, i.e. $n=$ $148(62.8 \%)$ were married and $129(54.4 \%)$ were males. Nearly two-thirds of the study participants, i.e. $n=$ $159(67.1 \%)$ were bachelor's degree by their academic qualification. Nearly half of the participants $n=118$ (49.8\%) had 6-10 years of experience as a nurse and 105 (44.3\%) had $\leq 2$ years' experience in ICU. The majority of participants, $\mathrm{n}=153(64.6 \%)$ used PR in the past month and nearly half of the participants $\mathrm{n}=$ 118 (49.8\%) were read information about PR in the past year. 81 (34.1\%) of the study participants were received educational training during their graduate class, but no one had gotten In-service training regarding restraining. The majority of the participants $n=136(57.6 \%)$ was observed complications associated with PR. The most frequent complication observed by nurses was edema, pain and bruising around the restrained part. Fatigue, agitation, anger, aspiration were the other types of observed complications associated with PR use among critically ill patients (Table 1). 
Table 1

Socio-demographic and professional characteristics of nurses working in ICU at ARSRHs, $2019(n=237)$

\begin{tabular}{|c|c|c|c|}
\hline Variables & & Frequency & $\begin{array}{l}\text { Percent } \\
\text { (\%) }\end{array}$ \\
\hline Sex & $\begin{array}{l}\text { Male } \\
\text { Female }\end{array}$ & $\begin{array}{l}129 \\
108\end{array}$ & $\begin{array}{l}54.4 \\
45.6\end{array}$ \\
\hline Participants religion & $\begin{array}{l}\text { Orthodox } \\
\text { Muslim } \\
\text { Protestant }\end{array}$ & $\begin{array}{l}181 \\
43 \\
13\end{array}$ & $\begin{array}{l}76.4 \\
18.1 \\
5.5\end{array}$ \\
\hline Marital status & $\begin{array}{l}\text { Unmarried } \\
\text { Married } \\
\text { Divorced }\end{array}$ & $\begin{array}{l}71 \\
148 \\
18\end{array}$ & $\begin{array}{l}30.0 \\
62.8 \\
7.6\end{array}$ \\
\hline Academic qualification & $\begin{array}{l}\text { Diploma } \\
\text { Bachelor's } \\
\text { Master's }\end{array}$ & $\begin{array}{l}25 \\
159 \\
53\end{array}$ & $\begin{array}{l}10.5 \\
67.1 \\
22.4\end{array}$ \\
\hline Work experience as a nurse & $\begin{array}{l}\leq 5 \text { years } \\
6-10 \text { years } \\
\text { More than } \\
10 \text { years }\end{array}$ & $\begin{array}{l}94 \\
118 \\
25\end{array}$ & $\begin{array}{l}39.7 \\
49.8 \\
10.5\end{array}$ \\
\hline Experience at ICU & $\begin{array}{l}\leq 2 \text { years } \\
3-5 \text { years } \\
\geq \text { years }\end{array}$ & $\begin{array}{l}105 \\
87 \\
45\end{array}$ & $\begin{array}{l}44.3 \\
36.7 \\
19.0\end{array}$ \\
\hline Use of PR in the past month & $\begin{array}{l}\text { Yes } \\
\text { No }\end{array}$ & $\begin{array}{l}96 \\
141\end{array}$ & $\begin{array}{l}40.5 \\
59.5\end{array}$ \\
\hline Reading about PR in the past year & $\begin{array}{l}\text { Yes } \\
\text { No }\end{array}$ & $\begin{array}{l}118 \\
119\end{array}$ & $\begin{array}{l}49.8 \\
50.2\end{array}$ \\
\hline $\begin{array}{l}\text { Received educational training in a graduate class } \\
\text { about PR }\end{array}$ & $\begin{array}{l}\text { Yes } \\
\text { No }\end{array}$ & $\begin{array}{l}81 \\
156\end{array}$ & $\begin{array}{l}34.2 \\
65.8\end{array}$ \\
\hline Use of alternative methods before PR & $\begin{array}{l}\text { Yes } \\
\text { No }\end{array}$ & $\begin{array}{l}125 \\
112\end{array}$ & $\begin{array}{l}52.7 \\
47.3\end{array}$ \\
\hline Number of patients care per day & $\begin{array}{l}2 \text { patients } \\
3-4 \text { patients } \\
\geq 5 \text { patients }\end{array}$ & $\begin{array}{l}59 \\
122 \\
56\end{array}$ & $\begin{array}{l}24.9 \\
51.5 \\
23.6\end{array}$ \\
\hline Observe complications from PR & $\begin{array}{l}\text { Yes } \\
\text { No }\end{array}$ & $\begin{array}{l}136 \\
101\end{array}$ & $\begin{array}{l}57.4 \\
42.6\end{array}$ \\
\hline Working shift time & $\begin{array}{l}\text { Day shift } \\
\text { Night shift } \\
\text { Day and/ night } \\
\text { Shift }\end{array}$ & $\begin{array}{l}66 \\
35 \\
136\end{array}$ & $\begin{array}{l}27.8 \\
14.8 \\
57.4\end{array}$ \\
\hline
\end{tabular}




\begin{tabular}{|llll|}
\hline Variables & Frequency & $\begin{array}{l}\text { Percent } \\
\text { (\%) }\end{array}$ \\
\hline Age & Range 23-40 & $\begin{array}{l}\text { Mean }= \\
\text { ( } 30.5\end{array}$ & $\begin{array}{l}\text { SD }=9.93 \\
\text { IQR }=28-\end{array}$ \\
& & Median & 33 \\
\hline
\end{tabular}

\section{Knowledge, attitude, and practice of nurses working in ICU regarding PR use}

The mean score of knowledge regarding PR among nurses working in the ICU was 7.81 ( $95 \% \mathrm{Cl} 7.56$, 8.05) with the standard deviation (SD) of 1.89, ranging from 4-11 (Table 2). The mean score of nurses' attitude regarding PR was $33.73(95 \% \mathrm{Cl} 32.89,34.56)$ with the standard deviation (SD) of 6.50 , ranged from 18-47 (Table 3). 
Table 2

Participant nurses knowledge response regarding PR use at ARSRHs, $2019(n=237)$

Items

Responses n (\%)

Correct

Incorrect

1. Physical restraints are safety, garments designed to prevent injury. $\quad 158(66.7)$

79

2. Restraints should be used when one cannot watch the patient closely.

153 (64.6)

84(35.4)

3. Patients are allowed to refuse to be placed in a restraint.

$169(71.3)$

68

4. If physical restraints (safety vest, garment) are to be used, a

$202(85.2)$

member of the patient's family is required to sign a consent form

5. Restraint should be released every 2 hours if the patient is awake.

$175(73.8)$

62

$(26.2)$

6 Restraints should be put on snugly so that there is no space between the restraint and the patient's skin.

$162(68.4)$

7. When a patient is restrained, the skin can break down or restlessness can increase.

$153(64.6)$

84

8. When a patient is restrained in bed, the restraint should not be attached to the side rail.

$153(64.6)$

9. A patient should never be restrained while lying flat in bed because of the danger of choking.

$172(72.6)$

10. Good alternatives to restraints do not exist.

$67(28.3)$

170

11. Deaths have been linked to the use of vest restraints.

$185(78.1)$

52

Knowledge total mean score with standard deviation

$7.81 \pm 1.89 ; 95 \%$

Cl: (7.56-8.05)

Range $=$ 4-11 
Table 3

Participant nurses attitude response regarding PR at ARSRHs, $2019(n=237)$

\begin{tabular}{|c|c|c|c|c|}
\hline & \multicolumn{4}{|c|}{ Responses (\%) } \\
\hline & SA & A & D & SD \\
\hline $\begin{array}{l}\text { 1. I feel that family members have the right to refuse the use } \\
\text { of restraints. }\end{array}$ & $\begin{array}{l}82 \\
(34.6)\end{array}$ & $\begin{array}{l}105 \\
(44.3)\end{array}$ & $\begin{array}{l}29 \\
(12.2)\end{array}$ & $\begin{array}{l}21 \\
(8.9)\end{array}$ \\
\hline $\begin{array}{l}\text { 2. If I were the patient, I feel I have the right to refuse or resist } \\
\text { when restraints are placed on me. }\end{array}$ & $\begin{array}{l}74 \\
(31.2)\end{array}$ & $\begin{array}{l}85 \\
(35.9)\end{array}$ & $\begin{array}{l}60 \\
(25.3)\end{array}$ & $\begin{array}{l}18 \\
(7.6)\end{array}$ \\
\hline $\begin{array}{l}\text { 3. I feel discomfort/guilty when placing a patient on } \\
\text { restraint. }\end{array}$ & $\begin{array}{l}50 \\
(21.1)\end{array}$ & $\begin{array}{l}107 \\
(45.1)\end{array}$ & $\begin{array}{l}73 \\
(30.8)\end{array}$ & 7 \\
\hline $\begin{array}{l}\text { 4. I feel that the main reason restraints are used is that the } \\
\text { hospital is short-staffed. }\end{array}$ & $\begin{array}{l}47 \\
(19.8)\end{array}$ & $\begin{array}{l}81 \\
(34.2)\end{array}$ & $\begin{array}{l}90 \\
(38.0)\end{array}$ & $\begin{array}{l}19 \\
(8.0)\end{array}$ \\
\hline $\begin{array}{l}\text { 5. I feel embarrassed when the family enters the room of a } \\
\text { patient who is restrained and they have not been informed. }\end{array}$ & $\begin{array}{l}68 \\
(28.7)\end{array}$ & $\begin{array}{l}78 \\
(32.9)\end{array}$ & $\begin{array}{l}74 \\
(31.2)\end{array}$ & $\begin{array}{l}17 \\
(7.2)\end{array}$ \\
\hline $\begin{array}{l}\text { 6. It makes me feel bad if the patients get more upset after } \\
\text { restraints are applied. }\end{array}$ & $\begin{array}{l}67 \\
(28.3)\end{array}$ & $\begin{array}{l}83 \\
(35.0)\end{array}$ & $\begin{array}{l}79 \\
(33.3)\end{array}$ & $\begin{array}{l}8 \\
(3.4)\end{array}$ \\
\hline $\begin{array}{l}\text { 7. It makes me feel bad when patients become more } \\
\text { disoriented after the restraints have been applied. }\end{array}$ & $\begin{array}{l}70 \\
(29.5)\end{array}$ & $\begin{array}{l}99 \\
(41.8)\end{array}$ & $\begin{array}{l}55 \\
(23.2)\end{array}$ & $\begin{array}{l}13 \\
(5.5)\end{array}$ \\
\hline $\begin{array}{l}\text { 8. A patient suffers a loss of dignity when placed in } \\
\text { restraints }\end{array}$ & $\begin{array}{l}61 \\
(25.9)\end{array}$ & $\begin{array}{l}129 \\
(54.5)\end{array}$ & $\begin{array}{l}39 \\
(16.2)\end{array}$ & $\begin{array}{l}8 \\
(3.4)\end{array}$ \\
\hline $\begin{array}{l}\text { 9. The hospital is responsible for adhering to the laws on the } \\
\text { use of restraints to ensure the safety of a patient. }\end{array}$ & $\begin{array}{l}60 \\
(25.3)\end{array}$ & $\begin{array}{l}114 \\
(48.2)\end{array}$ & $\begin{array}{l}48 \\
(20.2)\end{array}$ & $\begin{array}{l}15 \\
(6.3)\end{array}$ \\
\hline $\begin{array}{l}\text { 10. I feel that placing a patient in restraints can decrease } \\
\text { nursing care time. }\end{array}$ & $\begin{array}{l}51 \\
(21.5)\end{array}$ & $\begin{array}{l}71 \\
(30.0)\end{array}$ & $\begin{array}{l}97 \\
(40.9)\end{array}$ & $\begin{array}{l}18 \\
(7.6)\end{array}$ \\
\hline 11. I believe that restraints increase the risk of strangulation. & $\begin{array}{l}45 \\
(19.0)\end{array}$ & $\begin{array}{l}89 \\
(37.60\end{array}$ & $\begin{array}{l}73 \\
(30.8)\end{array}$ & $\begin{array}{l}30 \\
(12.7)\end{array}$ \\
\hline $\begin{array}{l}\text { 12. In general, I feel knowledgeable about caring for a } \\
\text { restrained patient. }\end{array}$ & $\begin{array}{l}39 \\
(16.5)\end{array}$ & $\begin{array}{l}122 \\
(51.5)\end{array}$ & $\begin{array}{l}54 \\
(22.8)\end{array}$ & $\begin{array}{l}22 \\
(9.3)\end{array}$ \\
\hline $\begin{array}{l}\text { Attitude total mean score with standard deviation } 18-47 \\
\text { ( } 56.1 \% \text { above mean) }\end{array}$ & $\begin{array}{l}33.73 \pm \\
\text { Cl: }(32.8\end{array}$ & $\begin{array}{l}.50 ; 95 \% \\
-34.56)\end{array}$ & Range & $18-47$ \\
\hline
\end{tabular}

The mean score of practice about PR among nurses working in the ICU was $30.94(95 \% \mathrm{Cl} 30.25,31.64)$ with the SD of 5.44 and it ranged from 19-40. Majority of the nurses i.e. $N=135(57 \%)$ responded "always" to the question "I try alternative nursing methods before physically restraining the patient" and nearly half of the nurses i.e. $\mathrm{N}=116(48.9 \%)$ also gave answer "always" for the question "I frequently evaluate and record the effect of physical restraint when it is applied to a patient", and half of the participants i.e. $\mathrm{N}=118(49.8 \%)$ responded that applying "sometimes" to the question "When physical 
restraint is applied. I record on the nursing charts the type of restraint used, the reason for adopting it, the time when the application commences, and the related nursing care required", whereas i.e. $\mathrm{N}=81$ (34.2\%) of the nurses responded "never" to question "I explain to the patient why the restraint is being applied". (Table 4) 
Table 4

Participant nurses practice response regarding PR use at ARSRHs, $2019(n=237)$

Items

Responses $n$ (\%)

Always Sometimes Never

1. I try alternative nursing methods before physically restraining the patient

135

(57.0)

$87(36.7)$

$15(6.3)$

2. When I restrain a patient, I make this decision only with a physician's order.

77

3. When I feel that the patient does not need to be restrained. I make this suggestion to the doctor

4. I answer the call for the patient who is restrained as soon as possible.

5. I check the restraint every two hours to make sure they are in the proper position.

6. I inspect the skin of the patient for abrasions or skin tears if I bath the Patient who is restrained.

7. I tell family members why the patient is being restrained.

8. I explain to the patient why the restraint is being applied

9. I tell the patient when the restraints will be removed.

10. More patients are restrained when we are short of staff than when we are fully staffed.

11. In our hospital staff members work together to discover ways to control patients' behavior other than the use of physical restraints.

12. I frequently assess if the restraint should be removed

13. When physical restraint is applied. I record on the nursing charts the type of restraint used, the reason for adopting it, the time when the application commences, and the related nursing care required.

14. I frequently evaluate and record the effect of physical restraint when it is applied to a patient

Practice mean score of the participants
67

(28.3)

97

(40.9)
116

(48.9)
(32.5)

$\begin{array}{lll}65 & 118(49.8) & 54 \\ (27.4) & & (22.8)\end{array}$

$98 \quad 90(38.0) \quad 49$

(41.4)

$98 \quad 96(40.5) \quad 43$

(41.4)

90

(38.0)

$104(43.9)$

43

82

$114(48.1)$

41

(34.6)

55

(23.2)

$101(42.6)$

81(34.2)

75

$107(45.1)$

55

(31.6)

$130(54.9)$

63

(18.6)

(26.6)

99

(41.8)

$106(44.7)$

32

(13.5)

$147(62.0)$

$23(9.7)$

$118(49.8)$

$22(9.3)$

$91(38.4)$

30

(12.7)

$30.94 \pm 5.44 ; \quad$ Range $=19-40$

$95 \% \mathrm{Cl}:$

$(30.25,31.64)$ 


\section{Factors associated with the nurses' practice regarding PR use}

Simple linear regression analysis showed that: age, sex, academic qualification, reading information about PR in the past year, received educational training about PR during a graduate class; years of experience in ICU, knowledge and attitude scores were the variables associated with practice regarding $P R$ use with $p$-value $\leq 0$. 1. Multiple linear regressions indicated: received educational training during graduate class about PR, short ( $\leq 2$ years) experience at ICU, knowledge, and attitude were factors significantly associated with nurses' practice score regarding PR use.

Nurses practice regarding PR use decreases among nurses with short ( $\leq 2$ years) experience in the ICU compared to nurses with long ( $\geq 6$ years) experiences, whereas practice increases among nurses received educational training during graduate class than those not received training. Practice regarding PR use among nurses is increasing as the nurses' knowledge and attitude score increases (Table 5). 
Table 5

Factors associated with nurses' practice regarding PR use by multiple linear regression, $2019(n=237)$

\begin{tabular}{|c|c|c|}
\hline Variables & $\begin{array}{l}\text { Crude unstandardized } \beta \\
\text { coefficient }(95 \% \mathrm{Cl}) \\
\text { Practice }\end{array}$ & $\begin{array}{l}\text { Adjusted unstandardized } \beta \\
\text { coefficient }(95 \% \mathrm{Cl})\end{array}$ \\
\hline $\begin{array}{l}\text { Sex } \\
\text { Male } \\
\text { Female }\end{array}$ & $\begin{array}{l}0 \\
-3.29(-4.62,-1.96)\end{array}$ & $\begin{array}{l}0 \\
-0.53(-1.66,0.60)\end{array}$ \\
\hline Age of nurses & $0.36(0.16,0.56)$ & $-0.03(-0.21,0.14)$ \\
\hline $\begin{array}{l}\text { academic qualification } \\
\text { Master's } \\
\text { Bachelor's } \\
\text { Diploma }\end{array}$ & $\begin{array}{l}0 \\
-1.39(-2.86,0.09) \\
-5.66(-7.81,-3.51)\end{array}$ & $\begin{array}{l}0 \\
0.48(-1.01,1.97) \\
-0.47(-2.90,1.95)\end{array}$ \\
\hline $\begin{array}{l}\text { Reading about PR in the } \\
\text { last year } \\
\text { No } \\
\text { Yes }\end{array}$ & $\begin{array}{l}0 \\
5.22(3.99,6.44)\end{array}$ & $\begin{array}{l}0 \\
1.09(-0.26,2.44)\end{array}$ \\
\hline $\begin{array}{l}\text { Training about PR by, } \\
\text { graduate class } \\
\text { No } \\
\text { Yes }\end{array}$ & $\begin{array}{l}0 \\
5.14(3.82,6.45)\end{array}$ & $\begin{array}{l}0 \\
1.49(0.16,2.82) \text { * }\end{array}$ \\
\hline $\begin{array}{l}\text { Work experience at ICU } \\
\geq 6 \text { years } \\
3-5 \text { years } \\
\leq 2 \text { years }\end{array}$ & $\begin{array}{l}0 \\
0.02(-1.43,1.47) \\
-2.73(-4.09,-1,37)\end{array}$ & $\begin{array}{l}0 \\
-0.72(-2.23,0.79) \\
-1.34(-2.47,-0.21) \text { * }\end{array}$ \\
\hline $\begin{array}{l}\text { Working time type } \\
\text { Regular day } \\
\text { Shift day or night } \\
\text { Shift day and night }\end{array}$ & $\begin{array}{l}0 \\
-2.32(-3.69,-0.94) \\
0.30(-1.66,2.27)\end{array}$ & $\begin{array}{l}0 \\
-1.06(-2.74,0.60) \\
-0.38(-1.97,1.21)\end{array}$ \\
\hline Knowledge & $1.52(1.21,1.83)$ & $0.40(0.03,0.78)^{\star}$ \\
\hline Attitude & $0.57(0.49,0.65)$ & $0.37(0.27,0.47)^{\star \star \star}$ \\
\hline \multicolumn{3}{|c|}{ Note; * $p<0.05, * * p<0.01, * \star * p<0.001$} \\
\hline Adjusted $R^{2}=50.2 \%, F-t$ & alue $<0.001$ & \\
\hline
\end{tabular}

\section{Discussion}

PR is widely used in intensive care unit settings among critically ill patients' to reduce the risk of a patient's falling, prevent removal of life support equipment and procedures, and reduce the risk of patients harming himself or others among (1). Physically Restrained patients in the ICU encounter prolonged hospital stays and complications results from restraint as a result of nurses' improper practices (behavior) of restraining $(6,17,18,31)$ which reduces power from even the most beneficial 
medical treatments (32). Improving nurses' practice on the use of restraining, therefore, is crucial to prevent the complication of it and to enhance ICU care service.

This study indicated that; mean total score of nurses' practice was $30.94 \pm 5.44$, which reflected the majority of the nurses' had satisfactory practices regarding PR use. The proportions of the nurses who score above the mean score were $56.5 \%$. It indicates that $43.5 \%$ of the participants had unsatisfactory practices regarding PR use. This result is agreed with the studies held in Jordan and India $(8,33)$. The mean score of this study is higher than the studies held in Egypt, Saudi-Arabia, and Malaysia (13-15). The possible reason for the variation might be attributed to that most of the participants in those studies were diploma in their educational qualification but the majority of the nurses in this study were bachelor's and master's in their educational level. So this finding supposed to increase the mean score of practice regarding PR use.

The nurses' practices mean score of this study is lower than the study held in Turkey and United States $(16,19,31)$. The difference of this result might be most of the participants in those studies were got Inservice training and the presence of hospitals guideline regarding physical restraint but there is no one who had took In-service training and absence of guidelines regarding PR for the care of critically ill patients. So this finding supposed to decrease the mean score of nurses' clinical practice.

Regarding predictor variables; short ( $\leq 2$ years) experience at ICU $(\beta=-1.34,95 \% \mathrm{Cl}:(-2.47,-0.21))$ was significantly associated with improper practice regarding PR use. The possible reason might be when the nurses had short years of experience; they are facing problems for applying the best nursing activities properly regarding physical restraints than long years of experienced nurses $(34,35)$. This finding was consistent with the previous study (15). This study showed that received educational training about PR during graduate class $(\beta=1.49,95 \% \mathrm{Cl}$ : $(0.16,2.82))$ had a positive correlation with nurses' practice regarding PR use. If nurses learned related to restraining in their graduate class, this influences them to have a piece of better subjective information (awareness), feeling and performs proper clinical practice regarding the restraining of critically ill patients. This indicates the need for effective educational training regarding restraining by developing the program aimed at maximizing understanding of patient's rights and autonomy, ethical and legal aspects of restraining patient, impact and dangers of PR and restraint alternatives $(13,36,37)$. This finding was consistent with other studies $(13,14)$ which showed proper practice regarding PR use was associated with nurses who had got training in their graduate class.

The nurses' knowledge score $(\beta=0.40,95 \% \mathrm{Cl}:(0.03,0.78))$ was positively associated with the nurses' practice score regarding PR use. The possible reason might be based on the theory of planned behavior, adequate knowledge of nurses is essential for the basis of their behavior to better subjective feelings regarding restraint use on critically ill patients and to perform appropriate nursing activities during constraints. This may increase the likelihood of a proper practice regarding restraint use on patients. This result is in agreement with other studies $(13,14,22)$. Indeed, this study showed that a higher attitude score $(\beta=0.37,95 \% \mathrm{Cl}:(0.27,0.47))$ was significantly associated with more proper nurses' practice regarding restraining. The possible reason might be that nurses' with better subjective feelings and 
beliefs about restraint use, put themselves in place of patients and their families on the use of PR. This feeling and thought can guide nurses to prefer alternative methods and performs them appropriately when used (14). This result is in agreement with other studies $(13,14,22)$. This reveals that in-service training for nursing staff concerning the physical restraining of ICU patients is crucial. The training can improve nurses' knowledge, attitude and then practice through the reduction of the frequency of complications related to PR among these patients (38).

The participants were nurses' who were motivated to participate in the study, which limits the external generalizability of the result. Practices regarding PR use were assessed via a self-report questionnaire, which might not reflect the actual behavior of nurses. Since the study design was cross-sectional, as a result of its nature; it is difficult to show the cause-effect relationship between predictors and nurses' practice regarding PR use.

\section{Conclusion}

The participant nurses' working in ICU at ARSRHs had a satisfactory practice regarding PR use among critically ill patients. There was a negative association between nurses' experience years in the ICU and nurses' practice regarding PR, positive associations between received of training regarding PR in graduate class knowledge, attitude and nurses' practices regarding PR use.

\section{Recommendations}

Based on the findings of this study, the researchers recommended the local administrators' to develop policies and provide educational and in-service training programs for nurses working in ICUs especially for those with less experience ( $\leq 2$ years) in ICU regarding PR use and its alternatives. It is important to improve nurses' practice regarding PR use. It is better if the researchers conducted a cohort study to observe whether nurses' experience of years, educational and in-service training can improve the staff's practice regarding PR use.

\section{Declarations}

\section{Ethics approval and consent to participate}

Ethical approval was obtained from the Institutions Review Board (IRB) of the University of Gondar. The Official letter of cooperation was submitted to all referral hospitals and then a formal letter of permission was obtained from each hospital. Before data collection, the aim of the study was explained verbally to the participants and after their willingness, written permission was obtained before filling the questionnaire. So an informed written consent was obtained from the participants and confidentiality was maintained by omitting their personal identification.

\section{Consent for publication}


Not applicable

\section{Availability of data and material}

The data sets used for the current study are available from the corresponding author on reasonable request (tilahunkassew123@gmail.com).

\section{Competing interests}

The authors declare that they have no competing interests

\section{Funding}

University of Gondar covers the cost (financial support) for personal expenditure, material fulfillment, transportation required for the study.

\section{Authors, contribution}

TKG developed the proposal, supervised the data collection, analyzed the data and wrote the draft manuscript. ADT revised the proposal and assist the data analysis. BLW revised the proposal and revised and approved the manuscript. Finally, all authors have read and approved the manuscript.

\section{Acknowledgments}

The authors wish to acknowledge each Hospital Director and the Head of the ICU wards for their kindly assistance during data collection to recruit nurses as participants in the study. The authors also would like to thank all of the participant nurses' who participated in this study.

\section{Abbreviations}

ARSRHs Amhara Regional State Referral Hospitals

ICU Intensive Care Unit

PR Physical Restraint

SPSS Statistical Packages of Social Sciences

\section{References}

1. Martin B. Restraint use in acute and critical care settings: changing practice. AACN Advanced Critical Care. 2002;13(2):294-306.

2. Bleijlevens M, Wagner L, Capezuti E, Hamers J, editors. A Delphi consensus study to determine an internationally accepted definition on physical restraints. Gerontologist; 2012: OXFORD UNIV PRESS INC JOURNALS DEPT, 2001 EVANS RD, CARY, NC 27513 USA. 
3. Eşer İ, Khorshid L, Hakverdioğlu G. The characteristics of physically restrained patients in intensive care units. Journal of Human Sciences. 2007;4(2).

4. Benbenbishty J, Adam S, Endacott R. Physical restraint use in intensive care units across Europe: the PRICE study. Intensive and Critical Care Nursing. 2010;26(5):241-5.

5. Jacobi J, Fraser GL, Coursin DB, Riker RR, Fontaine D, Wittbrodt ET, et al. Clinical practice guidelines for the sustained use of sedatives and analgesics in the critically ill adult. Critical care medicine. 2002;30(1):119-41.

6. Kirk AP, McGlinsey A, Beckett A, Rudd P, Arbour R. Restraint reduction, restraint elimination, and best practice: role of the clinical nurse specialist in patient safety. Clinical Nurse Specialist. 2015;29(6):321-8.

7. Rose L, Dale C, Smith OM, Burry L, Enright G, Fergusson D, et al. A mixed-methods systematic review protocol to examine the use of physical restraint with critically ill adults and strategies for minimizing their use. Systematic reviews. 2016;5(1):194.

8. Suliman M, Aloush S, Al-Awamreh K. Knowledge, attitude and practice of intensive care unit nurses about physical restraint. Nursing in critical care. 2017;22(5):264-9.

9. Mion LC. Physical restraint in critical care settings: will they go away? Geriatric Nursing. 2008;29(6):421-3.

10. Huang H-T, Chuang Y-H, Chiang K-F. Nurses' physical restraint knowledge, attitudes, and practices: the effectiveness of an in-service education program. Journal of Nursing Research. 2009;17(4):2418.

11. Wynn R. Staff's attitudes to the use of restraint and seclusion in a Norwegian university psychiatric hospital. Nordic Journal of Psychiatry. 2003;57(6):453-9.

12. Hine K. The use of physical restraint in critical care. Nursing in critical care. 2007;12(1):6-11.

13. Azab S, Abu Negm L. Use of physical restraint in intensive care units (ICUs) at Ain Shams University hospitals, Cairo. Journal of American science. 2013;9(4):230-40.

14. Eskandari F, Abdullah KL, Zainal NZ, Wong LP. Use of physical restraint: Nurses' knowledge, attitude, intention and practice and influencing factors. Journal of clinical nursing. 2017;26(23-24):4479-88.

15. El-sol AE-SH, Mohmmed RGA. Assessment of nurse's knowledge, attitudes, and practice regarding physical restraints among critical ill patients. Assessment. 2018;4(1).

16. Kaya H, Doğu Ö. Intensive care unit nurses' knowledge, attitudes and practices related to using physical restraints. International Journal of Caring Sciences. 2018;11(1):61-70.

17. Çelik S, Kavrazlı S, Demircan E, Güven N, Durmuş Ö, Duran ES. Knowledge, attitudes and practices of intensive care nurses related to using physical restraints. Acıbadem Üniversitesi Sağlık Bilimleri Dergisi. 2012;3(3).

18. Karagözoğlu Ş, Özden D. Knowledge and Practices of Nurses Wor-king Ata University Hospital Related to use of Physical Restraints. Hemar-G Derg. 2013;1:11-22. 
19. Stinson KJ. Nurses' attitudes, clinical experience, and practice issues with use of physical restraints in critical care units. American Journal of Critical Care. 2016;25(1):21-6.

20. Minnick AF, Mion LC, Johnson ME, Catrambone C, Leipzig R. Prevalence and variation of physical restraint use in acute care settings in the US. Journal of Nursing Scholarship. 2007;39(1):30-7.

21. Luk E, Burry L, Rezaie S, Mehta S, Rose L. Critical care nurses' decisions regarding physical restraints in two Canadian ICUs: A prospective observational study. Canadian Journal of Critical Care Nursing. 2015;26(4).

22. Suen LK, Lai C, Wong T, Chow S, Kong S, Ho J, et al. Use of physical restraints in rehabilitation settings: staff knowledge, attitudes and predictors. Journal of advanced nursing. 2006;55(1):20-8.

23. Gulpers MJ, Bleijlevens MH, Ambergen T, Capezuti E, van Rossum E, Hamers JP. Reduction of belt restraint use: long-term effects of the EXBELT intervention. Journal of the American Geriatrics Society. 2013;61(1):107-12.

24. Janelli LM, Stamps D, Delles L. Physical restraint use: a nursing perspective. Medsurg Nursing. 2006;15(3):163-8.

25. Eskandari F, Abdullah KL, Zainal NZ, Wong LP. The effect of educational intervention on nurses' knowledge, attitude, intention, practice and incidence rate of physical restraint use. Nurse education in practice. 2018;32:52-7.

26. Maccioli GA, Dorman T, Brown BR, Mazuski JE, McLean BA, Kuszaj JM, et al. Clinical practice guidelines for the maintenance of patient physical safety in the intensive care unit: use of restraining therapies-American College of Critical Care Medicine Task Force 2001-2002. Critical Care Medicine. 2003;31(11):2665-76.

27. Reigle J. The ethics of physical restraints in critical care. AACN Advanced Critical Care. 1996;7(4):585-91.

28. Janelli LM, Scherer YK, Kuhn MM. Acute/critical care nurses' knowledge of physical restraintsimplications for staff development. Journal of nursing staff development: JNSD. 1994;10(1):6-11.

29. Suen K. Knowledge, attitude and practice of nursing home staff towards physical restraints in Hong

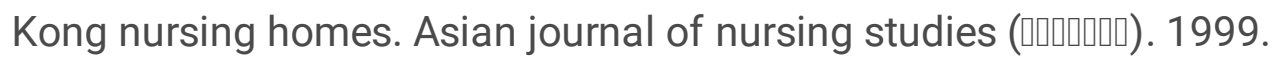

30. Kaya H, Aştı T, Acaroğlu R, Erol S, Savcı C. Nurses' knowledge, attitudes and practices related to using physical restraints. Maltepe Üniversitesi Hemşirelik Bilim ve Sanatı Dergisi. 2008;2:22-9.

31. Balci H, Arslan S. Nurses' Information, Attitude and Practices towards Use of Physical Restraint in Intensive Care Units. Journal of caring sciences. 2018;7(2):75.

32. Hall DK, Zimbro KS, Maduro RS, Petrovitch D, Ver Schneider P, Morgan M. Impact of a Restraint Management Bundle on Restraint Use in an Intensive Care Unit. Journal of nursing care quality. 2018;33(2):143-8.

33. Gandhi S, Poreddi V, Palaniappan M, Reddy N, Sai S, BadaMath S. Indian nurses' Knowledge, Attitude and Practice towards use of physical restraints in psychiatric patients. Investigacion y educacion en enfermeria. 2018;36(1). 
34. Al-Khaled T, Zahran E, El-Soussi A. Nurses' related factors influencing the use of physical restraint in critical care units. J Am Sci. 2011;7(8):13-22.

35. Younis GA, Sayed Ahmed S. Physical Restraint and Maintenance of critically ill patient's safety in Intensive Care Unit: Effect of Clinical practice guidelines on nurse's practice and attitude. Nurs Health Sci. 2017;6:6-21.

36. Evans D, Wood J, Lambert L, FitzGerald M. Physical restraint in acute and residential care: a systematic review. Database of Abstracts of Reviews of Effects (DARE): Quality-assessed Reviews [Internet]: Centre for Reviews and Dissemination (UK); 2002.

37. Vance DL. Effect of a treatment interference protocol on clinical decision making for restraint use in the intensive care unit a pilot study. AACN Advanced Critical Care. 2003;14(1):82-91.

38. Taha NM, Ali ZH. Physical restraints in critical care units: impact of a training program on nurses' knowledge and practice and on patients' outcomes. J Nurs Care. 2013;2(2):1-9. 